\title{
SUBCUTANEOUS EMPHYSEMA: A RARE COMPLICATION OF TONSILLECTOMY
}

\author{
Sharma R*, Abraham A L*, Shetty D*, Kumar A*, Singh A*, Reddy N S*
}

ABSTRACT

Cervical subcutaneous emphysema results from the entry of air into the muscle planes and subcutaneous planes. It can rarely be seen after tonsillectomy. We report this rare complication in a 20 year old female operated for chronic tonsillitis with history of peritonsillar abscess in past. The case is reported for its rarity. The pathogenesis and management of this complication is presented with the review of literature.

\section{Key Words: Tonsillectomy, Subcutaneous emphysema, Cervical.}

\section{INTRODUCTION}

Tonsillectomy is one of the most commonly performed surgeries. Subcutaneous emphysema occurs when air enters into the tissue and muscle planes. This can occur as a complication during or immediately after surgery. ${ }^{1}$ The purpose of this study is to share our experiences with this rare complication of tonsillectomy. Awareness of this unusual complication and its management will facilitate outcome of these patients and prevent secondary complications.

\section{CASE REPORT}

A 20 years old girl with hypertrophied tonsils was posted for tonsillectomy under general anaesthesia. She had history of two episodes of left peritonsillar abscess in the past for which she was hospitalized and required incision and drainage along with a course of broad spectrum antibiotics, analgesics and anti inflammatory drugs.

Tonsillectomy was done by dissection and snare method. Intraoperatively it was noted that the left tonsil was fibrotic.
Excessive dissection was required to separate the tonsil from tonsillar bed. There was a small tear of the left palatopharyngeal arch. Complete hemostasis was maintained throughout the procedure. The duration of surgery was 35 minutes. After oropharyngeal suctioning, patient was extubated. Immediate post operative phase was uneventful.

Next day, a diffuse swelling with ill-defined margins was noticed on left side of neck starting from the temporomandibular joint and down to the lower one third of the neck. On palpation, crepitus was present suggesting the diagnosis of subcutaneous emphysema. Examination of oropharynx and larynx was normal. X-ray soft tissue neck was done to confirm the diagnosis (Figure 1). X-ray chest was normal.

The patient was treated with broad spectrum antibiotics, analgesics and observed for progression of emphysema. By evening there was some decrease in the size of swelling which subsided in the next three days. The patient was discharged on fourth post operative day.

* Manipal College of Medical Sciences \& Manipal Teaching Hospital, Pokhara, Nepal.

Address for correspondence : Dr. Ravinder Sharma

Manipal College of Medical Sciences \& Manipal Teaching Hospital

Phulbari, P. O. Box: 341, Pokhara, Nepal

Email: rsharma45@yahoo.com 
Fig. 1

Fig.1 : X-ray Soft tissue Neck showing cervical subcutaneous emphysema on first post operative day.

\section{DISCUSSION}

Cervical subcutaneous emphysema results from the entry of air into the muscle planes and subcutaneous planes. The diagnosis is usually established by clinical examination. Palpation of the affected area reveals crepitus or crackling, an important diagnostic feature. It can be classified as spontaneous, ${ }^{2}$ traumatic ${ }^{3}$ or iatrogenic. ${ }^{4,5,6}$ Iatrogenic cervical subcutaneous emphysema is a rare complication in post operative patients after orthognathic laryngeal or oropharyngeal surgery. ${ }^{2}$

Sometimes a deeper than normal dissection can create a passage for air entry. This patient had fibrotic adhesions on left side possibly because of history of two episodes of peritonsillar abscess. We feel that the history of previous peritonsillar abscess, incision and drainage, excessive dissection and tear of the left palatopharyngeal arch were the predisposing factors in this case. This may be further facilitated by vomiting, coughing, straining and manual ventilation after extubation. The air passes through the fibres of superior constrictor muscle and finds its way easily into the parapharyngeal space. As parapharyngeal space and retropharyngeal space are connected, the air can escape in the retropharyngeal space and at hypo pharyngeal level can compromise the airway. Lower down it may involve the mediastinum and can lead to pneunomediastinum \&/or pneumothorax. $^{7}$

The initial onset of this complication can be seen during or immediately after extubation. The clinical course is generally self limited and benign, as the air is gradually absorbed from the tissues. At times it may lead to tension pneumothorax leading to circulatory/cardiac arrest ${ }^{8}$ or tracheal compression especially is young children in whom tracheal rings are soft ${ }^{9}$. Rarely it may involve peritoneal cavity. ${ }^{10}$
Provided there is no airway compromise, surgical emphysema can be treated conservatively. Conservative management includes broad spectrum antibiotics as implantation of organisms in soft tissues of neck can lead to infection, besides this restriction of oral intake and avoidance of maneuver which increases upper airway pressure like coughing, vomiting and straining helps in regression of subcutaneous emphysema. Complete resolution is appreciable within 2-5 days. ${ }^{11}$ In our case, the patient had improvement in subcutaneous emphysema by fourth day. Administration of $100 \%$ oxygen will help prevent the extension of air by increasing the gradient for reabsorption of nitrogen by reducing its partial pressure. ${ }^{7}$ Surgical repair of the disrupted mucosa with sutures to prevent secondary bacterial infection and extension of emphysema is rarely required. This should be reserved for cases which do not improve with conservative management. At the same time one should be aware of the consequences of delay is surgical intervention. In cases where there is airway compromise, tracheostomy may be considered.

\section{REFERENCES}

1 Hanpton SM G nnanond MT, Subcut aneous enphysenta as a cond i cation of Tonsi ll ectong. J. of Laryngd. and Qd ogy. 1977 ; V. 3 : 1077- 1078.

2 且 Grazal i ANS Spontaneous enphysena of the neck. J ournal of Laryngol ogy and Qdol ogy 1983; 97: 383-6.

3 Fl ood TR Medi asti nal enphysena conpl i cati ing a zygonati ic fracture. Acase repart and revi ewof literdure BitishJarnd of Oal and MAxil I of acial Surgery 1988; 26: 141-8.

4 Jash OK An unusual conpl i cati on during Adenotonsi I I ectony. J ournal of Laryngol ogy and Col ogy 1983 ; 87: 191-4.

5 Anderson BR Subcut aneous enphysent. Archi eves of Qol aryngol ogy 1958 ; 86: 697-9.

6 Snow B Surgi cal enphysena af ter tonsi I I ectony. J AMA 1965; 22: 191- 2.

7. Mnton G Tu HK Pneunonedi asteni um, Pneunothorax and cervical enohysera fol l owing nand bular fractures. Gal surg 1984; 57: 490-93.

8 Fri echan Q Chi dake A Lavess ST et. a. Postoperati ve bi l evel posi ti ve a rvay pressure verti I ati on after tonsi I l ectony and adena dectony in di I dren -a prel i minary report. I nternati ond J ournal of Ped atric Q Corhi nd aryngd ogy 1999, 51: 177-80.

9 Levi ne PA Hypopharyngeal perf orati on: an unt owar d conpl $i$ cat $i$ on of endotracheal intubati on. Archi eves of otol aryngol ogy 1980; 106: 178-80.

10. Sandl er CM Li bshi tz H, Marks G Pneunoperi t oneum, pneunonedi asti numand pneunoperi cardumf ol l ow ing dental extracti on 1975; 115: 539-40.

11. M man MC, Otturan Q Durnals $M$, Kal ci ogl u M, Ced k E. Cervi cal subcutaneous enphysena : An unusual conpl i cati on of Adenotonsi Il ectony Paed atri c Anaesthesi a 2001; J u y 11(4): 491-93.

$$
\text { ES L L L }
$$

